\title{
Economy of Ukraine: The analysis of the innovative way of the development
}

\section{Mykhaylo Luchko}

University of Computer Science and Economics in Olsztyn, ul. Jagiellońska 59, 10-283 Olsztyn, Poland

Doctor, Professor

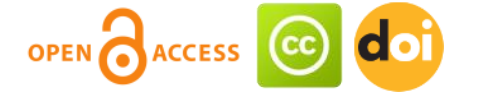

Article history:

Received: September 2, 2017

1st Revision: October 3, 2017

Accepted: October 25, 2017

JEL classification:

01

038

DOI:

10.14254/jems.2017.2-2.10
Abstract: Ukraine, unfortunately, is the poorest in Europe, being one of the largest territories and populations in it. After 25 years of independence, it de jure and de facto did not get independence, turning into a country - a big debtor. Today, all macro- and microeconomic indicators are disappointing in it. A significant problem is that its economy is a "war economy" now, which should be aimed at solving its own territorial problems. It is worth assessing the existing potential and systematically approaching the crisis for "recovery" despite its difficult condition. Taking into account the above, the theoretical exploration was made in the article, aimed at the practical solution of these problems.

Keywords: economy of Ukraine, innovations, development, crisis, concept, improvement of the economy, institutional changes, development concepts.

\section{Introduction}

The world is changing rapidly under the influence of the new economy, digital knowledge, progressive communication technologies and emergence of "techno-sapiens". The Robotic Process Automation of the economy, the study of artificial intelligence, imposes the need to change the paradigm of state formation and the continuous improvement of the mental level of productive forces of any country, regardless of the stage of its development.

What directions, changes, trends are the most probable today, and whether they are predicted or will affect the Ukrainian economy with a "whirlwind"? Will it remain on the brink of key social and economic processes, or will one jump be able to overcome years of lagging behind the leading economies of the world? In this direction, we have made a scientific exploration of Ukraine's capabilities. 


\section{Research results}

Exploring the economy today and, it is appropriate firstly to pay attention to the starting points of its origin, functioning and development opportunities in a competitive environment. I propose to take analogy and move in this direction by studying this issue, following a systematic approach. Firstly, it is worth giving the starting points of our arguments - the prerequisites and conditions of our vision.

At the second stage, we will focus on the objectively and subjective vision of the present and the plan of action, and complete the third stage, the most difficult, in which we will point out the known and unexpected obstacles that will be on the way of one of the most vulnerable economies in Europe. The starting points of our view is that no changes in the institutional sphere of society that bring about positive changes for the economy are impossible without the construction of a civil society, and hence the change in the way of thinking and mentality of its members. Today, all economies in Europe are closed with a number of similarities. There are similar problems of macroand microeconomic nature in the countries of the European Union, and therefore, apparently, similar ways should be found to solve them (Mentel, \& Horváthová, 2016; Draskovic, et al., 2017).

This is evidenced by the experience of weak and strong economies. But there are also initial contradictions that are related to national peculiarities, level of development, mentality. And hence, there are ways of interpreting national economies, which do not correspond to the strategies of the European Union and there are ways of interpreting the economies of the European Union, which are contrary to the interests of national economies (Unger, 2013). Therefore, a built-in system, whose task is to implement the norms of European legislation in order to harmonize them with the economies of individual countries or the coverage area of the economies (Unger, 2013).

Therefore, a built system, whose task is to implement the norms of European legislation in order to harmonize them with the economies of individual countries or the coverage area of the economy. However, free trade between economically unequal countries leads to enrichment of industrially developed countries and even greater poverty of countries with commodity economics, as the main feature of the modern economic world is imperfect competition. Only economies with a diversified production structure are growing. Deindustrialization leads to large migrations of the working population, as evidenced by the experience of the countries included in the European Union.

Ukraine was a country with a huge inert industrial potential after the collapse of the Soviet Union, a scientific base aimed at the development of the military-industrial complex, but with a weak economy and a lack of progress in state-building. It was one of the leaders in new space technologies, weapons production, educated people, and opportunities for the development of the agrarian sector. The communist party's human potential has carried out a robbery privatization of state property in its own interest but without having a clear strategy of where to move the country. Corruption is a sign of insufficient development of society.

It appeared and spread when people tried to survive at any price, despite their dignity and their subsequent consequences. As a result, 25 years of statehood have been lost, and thus a corrupt "oligarchy" has been built, which has developed through the plunder of the property of all the people.

Net foreign direct investment in Ukraine with the exception of those withdrawn from offshore countries is depicted below on the schedule. According to this indicator, Ghana, Bangladesh and Venezuela are neighbors of Ukraine (Fig. 1).

Ukraine's acquisition of competitiveness in the modern world is inextricably linked with the modernization of its economy. Entrepreneurship is an important component of mobilizing institutional factors to strengthen the competitiveness of the national economy, as evidenced by international experience.

Ukraine and the European Union became the starting point for a new way of economic development after signing of the Association Agreement. But the important strategic issue is that the development of the digital economy and intellectual infrastructure, fearlessness behind thoughtful experiments, the ability to think tactically and strategically, the proper realization of human potential, should become the main road signs in this way. This is explained by the fact that the main precondition for economic transformation in any underdeveloped economy is the emergence and development of new forms of production.

In recent years, we have realized that the path to the European Union is rather difficult and even tough. Competition between countries that surround Ukraine is not always carried out through diplomacy, sometimes using weapons or hybrid warfare. If we want to save the country, we have no other way out, how to determine its future and adapt itself to its path. 


\section{Figure 1: Net direct investment in Ukraine}

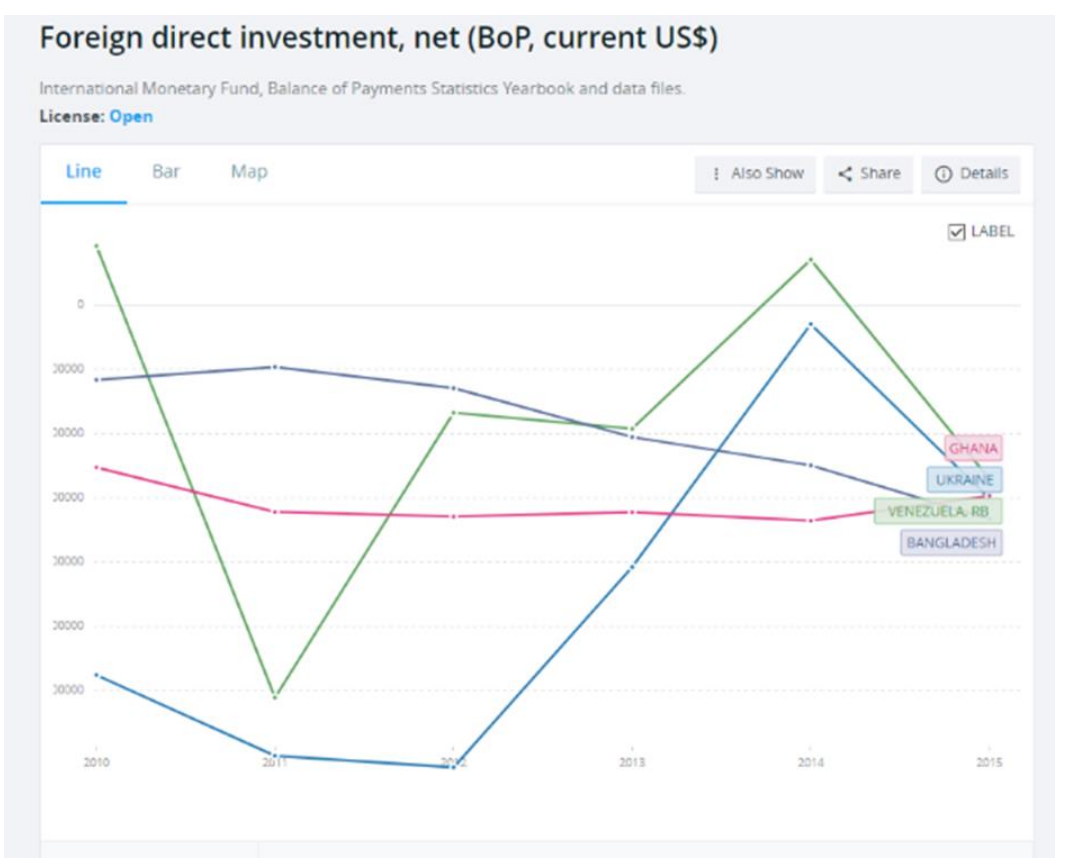

Source: (BusinessViews, 2017)

To be a country-producer of raw materials or raw material appendage of other countries is the way to nowhere. Without a strategy aimed at the country's ability or search, the movement will be slow and scholastic.

The analysis of the state of the entrepreneurial activity in Ukraine shows that the SME sector needs effective financial support both at the national and regional levels.

The world practice of development and protection of entrepreneurship shows that an affordable source of financing for small businesses is providing government guarantees for repayment of loans in case of insolvency of small enterprises. This reduces credit risks and eliminates the main obstacle to lending to small business entities, especially for beginners. But this requires appropriate credit resources of banks.

The positions of Ukraine in global rankings are unfortunately disappointing (Fig. 2).

Expanding the structure of proposals in the domestic market of goods and services, creating an effective competitive environment, stimulating innovation development, reviving the entrepreneurial initiative of the population, creating additional jobs and increasing flexibility of employment, strengthening regional economies are not all but very important tasks facing domestic business.

The analysis of the state of entrepreneurship shows that factors dominate in its internal environment, which reproduces the negative processes of the past: disorder and violation of the order of the system and the impossibility of self-development. Among the main ones, the following should be identified.

The technological state of the current economy is within the limits of the second and fourth technological methods, the limit technological potentials of which have already been exhausted for the growth of the economy. The leaders of the world economy compete within the fifth technological framework and generate the base for the transition to the sixth mode.

Therefore, one should draw the following conclusion: the existing plexus of the past, morally and physically obsolete technological structures that prevail in the modern Ukrainian economy makes any attempt by the state to reach the level of social development (the index of physical volume of GDP), which was achieved by Ukraine in 1990. The modern economy of Ukraine on the innovative aspect of its development cannot be built on such a technological basis (State Committee of Ukraine on Regulatory Policies and Enterprises, 2009).

The formation of market relations in a transitive economy will be achieved in the context of the formation of a modern private property institute and the emergence of a group of business on this basis, which is the leader of the dissemination and adoption of innovations. However, the new history of the formation of the institution of the private property and market relations, the construction of the business system has little to do with the logic of world business history. Incorrect, in the absence of the necessary legislative framework, the course of formation of the private property institute vulgarized the main principles of a market-driven competitive society. 
Figure 2: Positions of Ukraine in global ratings, 2015

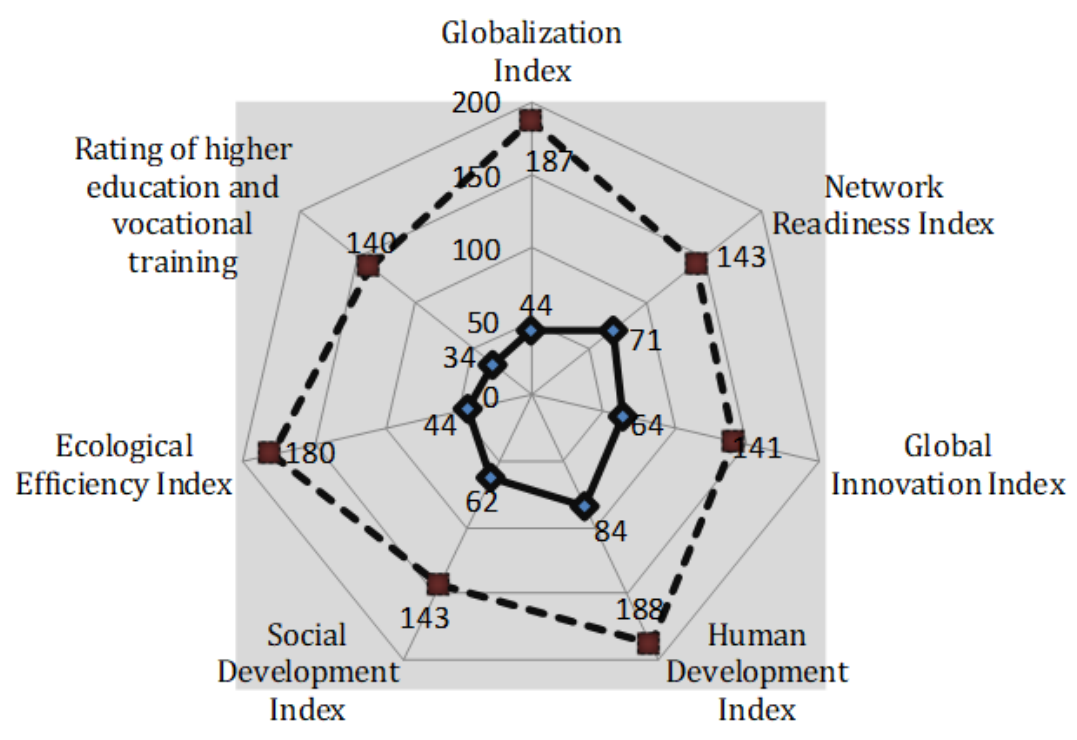

- the position of Ukraine - - the total number of studied countries

Source: Arzamasova, 2017

Unfair nature of the formation of property relations, the leader of which is a large business alone, has impartially created the necessary and sufficient conditions for the latter to enter the main branches of government. This led to monopolization of the whole economy not only in terms of natural monopolies. The economic policy of modern Ukraine depends on the interests of big business. Therefore it is impossible to create a system of balanced independent entrepreneurship, which should connect large, medium, small entrepreneurship and individual business.

The policy of institutional development of the state, equivalent to the requirements of time is an integral part of the process of stimulating the foundations of the formation of a system of effective development under conditions of a transitory economy.

One of the central state institutions of the intermediate economy is the law institute. The effectiveness of this institution and its effective influence on the formation of the market is directly dependent on the existing platform of the main priorities of economic development. The institutional field of doing business in Ukraine should be aligned with the priorities of the European perspective of the country. Its overall effectiveness must be measured by the influence of all its components, consolidated to ensure implementation of the strategy of ascension.

Following the logic of our article, there is a need to substantiate the modern approaches to the formation and implementation of economic development policy taking into account the influence of the innovative and investment model of the rise of Ukraine's economy in the context of world globalization processes.

The main dominant factor in ensuring Ukraine's competitiveness in the global economy is the urgent creation of conditions for the construction and implementation of a balanced innovation policy. It should be implemented in the scope of the developed, adopted program, tactics and strategy of economic development of the country.

The expected effectiveness of the economic strategy should be achieved by a targeted program of economic development priorities based on indicative planning based on a scientifically sound long-term forecast. The state of Ukraine should determine the natural and indicative cost indicators of its strategic innovation development in relation to the selected priority macroeconomic branches of the economy.

The following main directions in the strategic development plan of Ukraine should be: 1) industry of the fourth technological structure: nuclear power engineering, aircraft, rocket and shipbuilding, electronic industry, gas production and processing, fiber optic and computer technology, software, telecommunications, information services; 2) branches of the fifth technological system: nanotechnology, molecular biotechnology, genetic engineering, artificial intelligence systems, flexible automation, space technologies, the creation of materials with predetermined properties, the use of hydrogen as the main energy source (State Committee of Ukraine on Regulatory Policies and Enterprises, 2009). 
International experience shows that there is only one advantage over other countries in countries with a weak economy - low starting position, "the advantage of lagging behind". It lies in the prospects for large-scale borrowing of technology for enterprises, modern technical equipment and management methods adapted to rational economic requirements in line with the strategy of innovation development. The intentions of economic development inevitably depend on the observance of the necessary foundation for its innovative direction in a transitive economy.

The first steps on the way to the development should be such blocks of innovations, aimed at building up its own innovation and technology base.

First, these are life support technologies: quality products, housing, medicines that can be purchased by impoverished populations, roads and communications. This is a sort of anti-poverty program.

The second block is the import of technologies and the development of import-replacing technologies. This is a program of support of the domestic manufacturer.

The third block is the innovations for the development of a small business, the emergence of which is possible only with consistent compliance with the algorithm of development and implementation of the strategy. Today is the earliest creation and prospects of IT companies. But in Ukraine, the IT sector is a commodity economy, oddly enough, because it is $90 \%$ of its structure services in the form of outsourcing. Therefore, they do not affect the economic indicators and GDP of the country.

Priority directions of the development of innovative economic development require radical changes in approaches to education. The main driving force in the innovative sphere is the creative elite that has high-quality education, is able to translate knowledge into concrete projects, products, services and possesses the organizational skills that are necessary for innovation activity. This requires the need for a cautious attitude towards programs for the modernization of education, paying special attention to the fact that they are aimed at achieving a socially meaningful result, and not on secondary issues in the process of acquiring education.

We mean the laying of the foundations for the formation of a new social innovative and entrepreneurial mentality on the basis of the permanence of the knowledge preferences. There are good assets for this in Ukraine (Fig. 3). The highest form of forced innovation development of the economy on the basis of knowledge preferences should be the process of creating the fundamentals of competitiveness of innovation parks, the results of which should serve as an example for the entire business environment. In this way, Ukraine lags behind (Fig. 4).

Figure 3: High School Collaboration Index, science with highly technological industry in 2016

High School Collaboration Index, science with high-tech industry

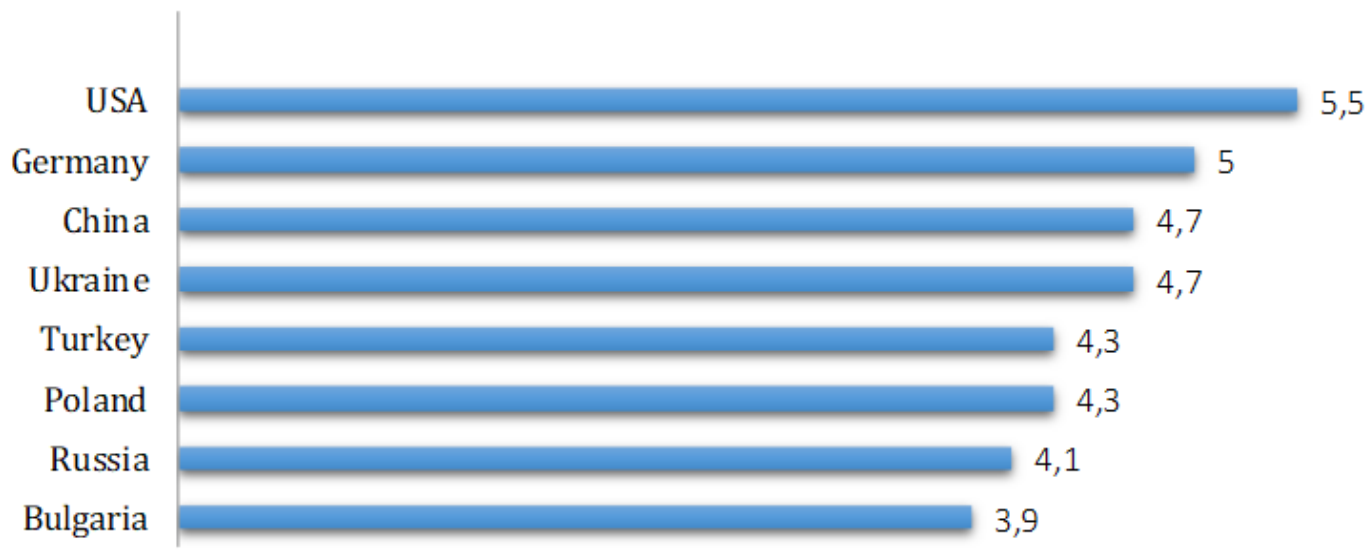

Source: Weforum, 2017

The worst performance, according to The World Economic Forum (Davos) are also the following: protection of property rights (131 st position), protection of minority shareholders (136), road quality (134), inflation (136), antitrust policy (136), impact of taxation on incentives up to investment (133), complexity of customs procedures (130), influence of rules on foreign investments (130), solvency of banks (138), stock market regulation (137) (Ukrainian Pravda, 2017).

This requires new state approaches to the creation of institutional and infrastructural institutions to ensure the implementation of programs for the creation of technological polices, scientific and technological centers, regional technical and technological clusters. 
Figure 4: The Global Competitiveness Index of countries in 2016

The Global Competitiveness Index

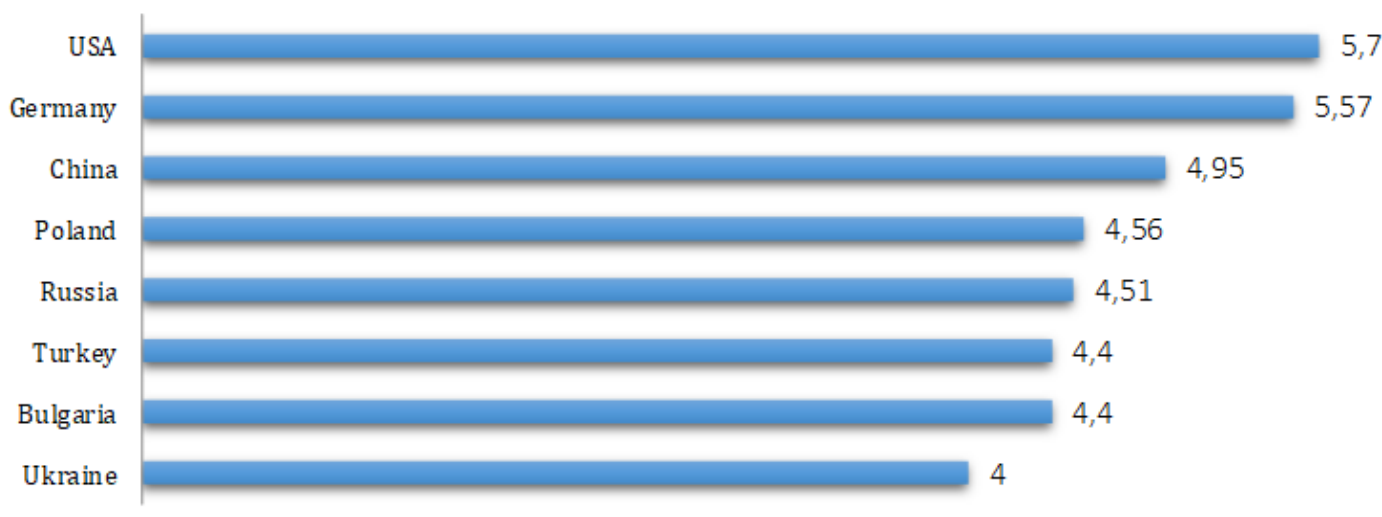

Source: Weforum, 2017

The stimulation of a common business environment for effective self-development on the basis of new knowledge acquired by such innovations incubators can take place only under one principal condition - the latter should not be subject to the commercialization of their knowledge, but have legally defined organizational and financial and tax privileges for implementing the strategy of self-development by obtaining more and more new scientific and technological advantages. Otherwise, the contradictions between short-term market outlooks and long-term strategic approaches cannot be avoided.

The above motivates the construction of the relevant projects for the implementation of the strategy of modernization of innovative economic development on the way of implementation of European legislation (Fig. 5).

Concluding the statement of the main part of the arguments, one should pay attention to those obstacles and "pitfalls" that will inevitably pursue the above-mentioned path ahead. Despite the wide populism, dogma and orthodoxy of views, their solution is possible only by changing the mentality and education of the productive forces of society, of the population. What should point out initially is to confront the broad unification of the interests of the "oligarchic" clan of society.

Only the creation of an alternative to it - a coalition of nationally conscious small and medium-sized businesses will make it possible to overcome the imbalances in the national economy. An important element on this path is the construction of civil society and the transparency of all its branches (Unger, 2013).

In the short-term perspective, priority should be given to the "purulent wounds" of the Ukrainian economy, which make innovation impossible. These are smuggling (import and export), cash flow and taxation system.

Comparison of statistical tables for 2015 Központi Statisztikai Hivatalt (Hungary), Štatistický úrad Slovakskej republiky (Slovak Republic), statistical yearly Institutul Nationalde Statistica (Romania) and Główny Urząd Statystyczny (Poland), data on foreign trade from Ukrainian Statistics and Belarus Statistics, gave an opportunity to form a Table 1.

In Ukraine's trade and five neighboring countries, the level of smuggling for 2015 can be estimated at approximately $\$ 2.012 .842 .000$. For comparison, the total trade turnover with these countries (according to Ukrainian Statistics) amounted to \$11.842.845.300 for 2015 .

But 5 neighboring countries are just $15.66 \%$ of Ukraine's foreign trade in 2015 . If we extrapolate the average smuggling of data to all countries, then the volume of smuggling is about 12 856982000 dollars. This, if not more, can be compared with the total amount of financial assistance (including loans from international financial organizations) of Ukraine. These data for 2015 are the year of the maximum collapse of Ukraine's foreign trade (Volynnews, 2017). 
Figure 5: Projects for the achievement of innovative economic development

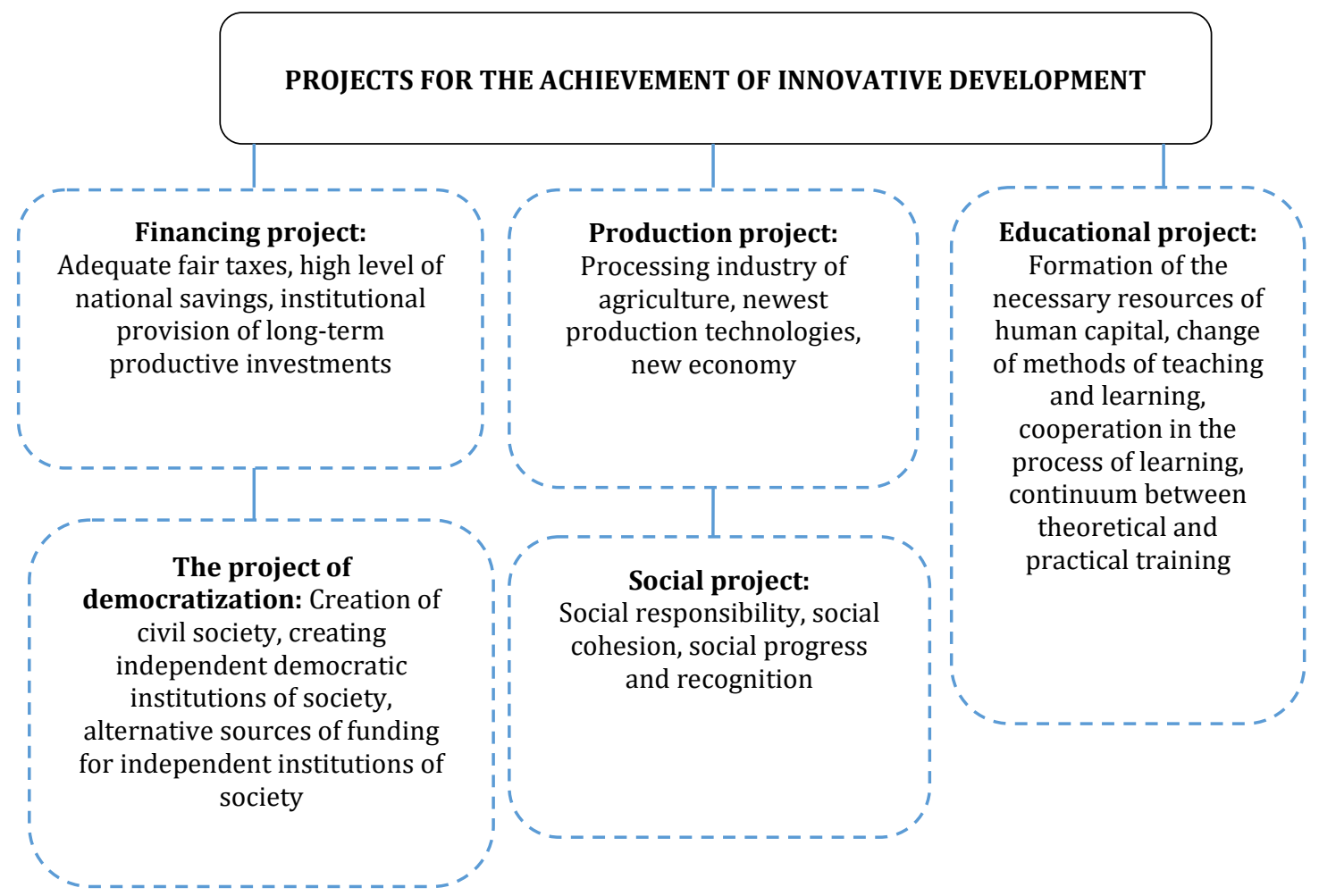

Source: Unger, 2013

Table 1: The share of possible smuggling in 2015 with individual countries, \%

\begin{tabular}{lcc} 
Country & Export & Import \\
\hline Poland & 14.07 & 42.07 \\
Slovak Republic & 13.42 & 0.03 \\
Hungary & 17.98 & 17.50 \\
Romania & 11.92 & 10.05 \\
Belarus & 9.28 & 2.68 \\
\hline
\end{tabular}

The country has free cash flow and weak legislative restrictions on it. Its implementation is carried out in $60 \%$ due to missing cash registers, and therefore because of not documenting the facts of the purchase-sale of goods. As a result, there is a "dark" money supply that leads to illegal enrichment, non-payment of personal income tax. The institutional resolution of this issue and the introduction of mechanisms for its implementation are the key to the balanced functioning of the National Bank of Ukraine, the strengthening of the national currency.

The introduction of the Tax Code of Ukraine, the change of the functions of the state fiscal service has become a powerful step towards the formation of a healthy tax climate in the country, and, therefore, investment attractiveness. At the same time, in our view, in a country with an unformed tax culture, the desire to avoid paying taxes, reducing tax burden, applying a simplified system, taxation should be aimed at developing business potential, rather than obtaining tax preferences over long periods of time without social responsibility for conducting entrepreneurial activity.

Consequently, a simplified tax system for doing business should be the motive for its innovative development, through its continuous development, rather than the mechanism for the implementation of unregistered cash circulation, the sale of trafficked goods, the development of tax avoidance schemes for large businesses, and the shadowing of the economy.

It is worth paying attention to the problem of finding the ideas of education. Its focus on the labor market necessitates decisive changes and revision of the training paradigms. According to the analytical center CEDOS, the number of Ukrainian studies at foreign universities as of the academic year 2014/2015 was 59.648 persons. Poland, Germany, Russia, Canada, Italy, Czech Republic, the USA, Spain, Austria, France and Hungary are still among the most desirable countries to study. 
According to analysts of the center, growth dynamics from 2009 through 2015 amounted to 129\%. Often, Ukrainians choose namely Polish universities. Thus, 20.5 thousand Ukrainian citizens studied in Polish universities in 2015 according to the data of the Directorate General of Statistics of Poland. And these are only complete programs that, after graduating, give a diploma. Also, there are many semesters or annual internships (Ukrainian Pravda, 2017).

\section{Conclusion}

Alternatively, it's probably worth referring to the practice-oriented education in domestic universities in the first stage of the educational process (bachelor) and developmental life-long learning models. But the problem of education in Ukraine is significant. Permanent educational experiments conducted at the state level, their incompleteness, poor institutional provision, led to a massive outflow of scientific personnel from Ukraine. The training of high-skilled scientific personnel is unjustifiably increasing, which can testify to their low level. The analysis shows that $75 \%$ of the scientific staff does not have an experience of practical work, and their scientific and practical training takes place formally.

This, of course, is not a complete recipe for recovery, since a chronically ill organism requires not only surgical therapy but also preventive measures. Therefore, without claiming the complete scientific and practical completeness of the views set forth above, we believe that their implementation in practice will have a significant positive effect.

\section{Appendix A. Supplementary material}

Supplementary data associated with this article can be found, in the online version, at https://dx.doi.org/10.14254/jems.2017.2-2.10.

\section{Funding}

The authors received no direct funding for this research.

\section{Citation information}

Luchko, M. (2017). Economy of Ukraine: The analysis of the innovative way of the development. Economics, Management and Sustainability, 2(2), 95-103. doi:10.14254/jems.2017.22.10 .

\section{References}

Arzamasova, O. V. (2017). Upravlinnia kadrovym potentsialom derzhavy $v$ umovakh pobudovy novoi ekonomiky [Management of the personnel potential of the state in the conditions of building a new economy]. Thesis abstract for Cand. Sc. (Econ.), Ternopil, Ukraine: TNEU. Retrieved from http://www.tneu.edu.ua/science/abstracts_of_theses/11838-arzamasova-oksanaviktorivna.html.

BusinessViews. (2017). 26 billion dollars - hidden opportunities for investments in the economy of Ukraine (and this is at least). Retrieved September 14, 2017 from http://businessviews.com.ua/ru/business/id/26-milliardov-dollarov-skrytyevozmozhnosti-dlja-investicij-v-ekonomiku-ukrainy-i-eto-kak-minimum-1651/. [in Russian].

Draskovic , M ., Milica, D., Mladen, I.,\& Chigisheva, O. (2017). Preference of institutional changes in social and economic development. Journal of International Studies, 10(2), 318-328.

Luchko, M. (2015). Dynamics of investment and innovation development of Ukraine: realities and prospects. Sotsialno-ekonomichni problemy i derzhava, 1(2), 96-106.

Luchko, M., \& Tereshchuk, H. (2013). Labour migration in Ukraine: economic, social and psychological effects. Problemy Profesjologii, 2, 187-192.

Mentel, G., \& Horváthová, Z. (2016). Factors of Efficiency of Open Investment Funds in 1997-2015. Economics and Sociology, 9(1), 101-113.

State Committee of Ukraine on Regulatory Policies and Enterprises (2009). National report of the State Committee of Ukraine on Regulatory Policy and Entrepreneurship on the state and prospects of entrepreneurship development in Ukraine. Retrieved from www.dkrp.gov.ua/files/a7feb.doc. 
The World Bank. (2017). Ukraine Economic Review, April 2017. Retrieved from http://www.worldbank.org/uk/country/ukraine/publication/economic-update-spring2017

Ukrainian Pravda. (2017). Brains to go?. Retrieved January 26, 2017 from https://life.pravda.com.ua/columns/2017/01/26/222278.

Unger, R. (2013). The content of the progressive national alternative. Retrieved February 11, 2013 from http://fundgp.com/ru/events/news/824/.

Volynnews. (2017). How many billions of dollars Ukraine loses in smuggling. Retrieved July 6, 2017 from https://www.volynnews.com/news/all/skilky-miliardiv-dolariv-ukrayina-vtrachayena-kontrabandi.

Weforum (2017). The Global Competitiveness Report 2016-2017. Retrieved from http://www.weforum.org.

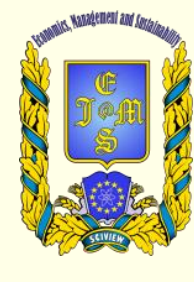

(c) 2016-2017, Economics, Management and Sustainability. All rights reserved.

This open access article is distributed under a Creative Commons Attribution (CC-BY) 4.0 license.

You are free to:

Share - copy and redistribute the material in any medium or format Adapt - remix, transform, and build upon the material for any purpose, even commercially.

The licensor cannot revoke these freedoms as long as you follow the license terms.

Under the following terms:

Attribution - You must give appropriate credit, provide a link to the license, and indicate if changes were made.

You may do so in any reasonable manner, but not in any way that suggests the licensor endorses you or your use.

No additional restrictions

You may not apply legal terms or technological measures that legally restrict others from doing anything the license permits.

Economics, Management and Sustainability (ISSN: 2520-6303) is published by Scientific Publishing House "CSR", Poland, EU and Scientific Publishing House "SciView", Poland

Publishing with JEMS ensures:

- Immediate, universal access to your article on publication

- High visibility and discoverability via the JEMS website

- Rapid publication

- Guaranteed legacy preservation of your article

- Discounts and waivers for authors in developing regions

Submit your manuscript to a JEMS at http://jems.sciview.net or submit.jems@sciview.net 